\title{
Research on Construction of Innovation and Entrepreneurship Education Ecosystem in Higher Vocational Colleges Based on Process Orientation
}

\author{
Lei Wang \\ Changzhou Vocational Institute of Engineering, Changzhou, 213164, China
}

Keywords: Process orientation, Innovation and entrepreneurship education ecosystem, Eco-subsystem, Construction approach.

\begin{abstract}
With the gradual transformation of China's economic growth mode and the gradual transformation of industrial structure, the requirement on innovation ability and entrepreneurial consciousness of higher vocational college students also becomes higher and higher. Construction of innovation and entrepreneurship education system in higher vocational colleges becomes the important goal of educational system reform. Starting with the concept explanation of innovation and entrepreneurship education system, this paper, based on process orientation, analyzes the construction of innovation and entrepreneurship education ecological subsystem in higher vocational colleges, and puts forward some ideas and approaches to search for a new way for innovation and entrepreneurship education eco-subsystem in higher vocational colleges.
\end{abstract}

\section{Concept analysis of innovation and entrepreneurship education ecosystem}

\section{Concept analysis of Innovation and entrepreneurship}

Innovation is a kind of new conceptual theory, with the new invention, new idea and new thinking as basic characteristics. The concept of innovation originated from the Austrian economist, Joseph Schumpeter. He pointed out that, in the production system, re-integration of the existing production conditions and factors is an innovative process, and based on innovation, liberate and develop productive forces to protect the profitability. Innovation includes three aspects of meaning, including product change, new products creation and product upgrading. The concept of innovation was introduced into our country at the end of the last century, putting more emphasis on the transformation of thinking level, and applied in the technical, institutional and theoretical principles and other aspects, and forming different sub-concepts in different areas. At the same time, the concept of innovation not only sets off a wave in our theoretical circles, and related industry experts and scholars apply the new concept into practice, providing a new theoretical basis for China's economic construction.

The concept of entrepreneurship first appeared and became popular in the United States, presented by the economist, Jeffrey Timmons. He believed that entrepreneurship should be based on business opportunities, combined with thinking and reasoning, comprehensively considering social background and development trends, and requires entrepreneurs to have outstanding leadership. The entrepreneurship concept has narrow and broad sense. The narrow sense of entrepreneurship refers to activities in which the entrepreneur, for the purpose of the realization of his own value, through the formation of a company or studio, provides services to the community. And the broad sense of entrepreneurship more focuses on entrepreneurial behaviors, and refers to the process of the integration of resources to create new values for all areas of society. At present, the concept of entrepreneurship is more popular in youth groups. A lot of graduated or graduation students will choose entrepreneurship to achieve the value of life and the pursuit of ideals.

During introducing and applying the concept of entrepreneurship, our country creatively combines the concept of entrepreneurship with the innovation, and puts forward the new teaching idea of 
innovation and entrepreneurship education. Innovation and entrepreneurship education also includes entrepreneurship concept and innovation ideas, different but mutually influenced. In terms of content emphasis, entrepreneurship is biased towards behavior creation activities, and innovation emphasizes the level of thinking consciousness; at the same time innovation is the key to determine the success of entrepreneurship, and entrepreneurship promotes the development of innovative thinking. Both concepts are inseparable.

\section{Concept analysis of Innovation and entrepreneurship education ecosystem}

The pioneer of the concept of innovation and entrepreneurship education ecosystem is the British ecologist, Arthur George, who defined the concept of ecosystems as that, ecosystem means the relatively stable dynamic system in a given area constructed together by the environment and the biology through interacting and constraining each other. The goal of construction of innovation and entrepreneurship education ecosystem in higher vocational colleges is to cultivate students' sense of innovation, to improve their entrepreneurial skills, and to integrate subsystems, including government, university, enterprise and family. These subsystems are interrelated and mutually united, to form a relatively stable education system.

\section{Analysis on innovation and entrepreneurship education ecosystem in higher vocational colleges based on process orientation}

The ultimate goal of construction of innovation and entrepreneurship education ecosystem in higher vocational colleges is to improve the ability of innovation and entrepreneurship of college students. This is also the requirement of China's economic development, industrial transformation and upgrading and manufacturing promotion on contemporary college students. The construction of educational ecosystem is a complex and long process, necessary to integrate various social resources, and play the forces in all walks of life to build a benign system. Education ecosystem is formed by four indispensable subsystems, including the government, university, enterprise and family.

\section{Government eco-subsystem}

The government's policy measures are the basic conditions for the construction of innovation and entrepreneurship education ecosystem in higher vocational colleges. Government policies can define a correct development direction for innovation and entrepreneurship education. With the progress of enrollment in colleges and universities, the number of students in colleges is increasing, and the employment situation of graduates is not optimistic. These conditions require the government to take measures to broaden the employment channels of college students, and increase employment opportunities. At the same time, economic change and industrial transformation have the growing demand for innovative and entrepreneurial talents. In the field of public opinion, the government should increase the publicity of the spirit of innovation and entrepreneurship, strengthen the guidance of public opinion, inspire the vitality of innovation and entrepreneurship of the community, to create a good social atmosphere and cultural atmosphere for college students, so that the whole society can participate in supporting and encouraging students' entrepreneurial activities.

\section{University eco-subsystem}

First of all, colleges and universities should accurately locate training program and training objectives of innovative and entrepreneurial talents. "Scientific research, teaching and service" is the foundation of traditional teaching system talent training program and target design. The innovation and entrepreneurship education system requires talent training program to be revised according to the goal of innovation and entrepreneurship teaching, and realize the deep integration of professional teaching and innovation and entrepreneurship teaching. At present, innovation and entrepreneurship class teachers in higher vocational colleges are mainly full-time teachers. Some of these teachers are economics, management teachers, although they have a wealth of theoretical knowledge, but lack practical entrepreneurial experience, they cannot provide practical guidance in entrepreneurship activities; some are the faculty of department of student affairs, busy and difficult to devote all energy 
into the innovation and entrepreneurship course teaching. There are some part-time teachers, mainly industry experts and entrepreneurs, etc. They usually have the experience of hard work in the industry for many years, but lack sufficient teaching ability, unable to master teaching process and objectives. Based on this, higher vocational colleges need to establish stable and powerful faculty strength, encourage teachers to participate in skills seminars or related knowledge training, improve the knowledge structure, and establish a new teaching philosophy. For school full-time teachers, who lack practical entrepreneurial experience, regularly organize them to enter the enterprise to study and learn from the entrepreneurial experience through close contact with entrepreneurs.

\section{Enterprise eco-subsystem}

Industry is the hub to maintain vocational colleges and industrial chain, and enterprise is the main body of advanced productive forces. Industry enterprises are the vane for higher vocational colleges to cultivate high-quality innovative and entrepreneurial talents. From the enterprise side, build the school-enterprise cooperation, and integrate the project sector, production workshop, research and development center and other production processes into curriculum planning and design, training programs development, curriculum teaching activities in higher vocational colleges. Through this approach, enterprises can advance the time of talent training to the school time of students, eliminating the training energy and cost for graduates before going on duty. At the same time, higher vocational colleges introduce enterprises into curriculum setting, and complete the teaching plan according to enterprises' requirements of talents, to ensure the correct orientation of talent training programs, thereby improving the employment rate of school graduates. At present, a major factor concerning construction of innovation and entrepreneurship education system in higher vocational colleges is the lack of teachers, and school-enterprise cooperation will introduce entrepreneurs and management personnel into the teaching process. The rich practice and management experience of these entrepreneurs will enhance the teaching quality, and play a huge role in innovation and entrepreneurship talents cultivation in higher vocational colleges.

\section{Family eco-subsystem}

Influenced by the traditional family education concept, current college student parents generally do not support their children for entrepreneurship. First, parents want their children to make somewhat academic achievement; second, there is a certain risk for self-entrepreneurship, and parents generally hope that children can have a stable job and income. These traditional ideas will kill children's self-confidence, self-thinking ability and creativity, combat their self-reliance, and are not conducive to cultivating students' innovative and entrepreneurial thinking. Family is the second largest place for students' education, and its importance cannot be replaced. The family's educational concept, education methods and educational means will subtly influence on children's characters and personality. Therefore, parents must change this traditional concept, and actively encourage their children to think, to do, and to strive. In daily lives, they can buy for relevant economics and management books for children, to fill their knowledge base, and intake relevant knowledge and experience. In addition, in their work, they should also actively use the concept of innovation and entrepreneurship, to take the lead example for children with their own actions.

\section{Construction approach of innovation and entrepreneurship education ecosystem in higher vocational colleges}

To realize the construction of innovation and entrepreneurship education ecosystem in higher vocational colleges, we need to integrate the power of society, enterprise, university, and family, mainly from the following aspects.

\section{Theoretical innovation}

Innovation and entrepreneurship theory is the basis of innovation and entrepreneurship education. There are many shortcomings for the traditional education model, such as emphasis on theory, indifference to practice, obsolescence of knowledge, boring classroom teaching form, blindly 
knowledge indoctrination and lack of ability training. Innovation and entrepreneurship education system breaks through this traditional educational philosophy and teaching mode, to strengthen the cross-disciplinary integration, and pay attention to cultivate students' practical ability. Therefore, the theoretical education of innovation and entrepreneurship education should be carried out from the following aspects. First, pay attention to the flexibility of teaching courses, in the development of professional courses and compulsory courses, at the same time set elective courses to achieve combination of the point, line, and surface, so that students can select courses according to their advantages to ensure personalized development of their personality and ability; second, focus on the diversity of guidance forms and coverage, and combine sub-project guidance and comprehensive guidance, to help students firmly grasp the knowledge of each sub-section, also to integrate Knowledge framework, so as to lay a solid theoretical foundation for the future employment; third, meanwhile in the general education activities, integrate into elite education courses, and based on the teaching coverage of all students, select outstanding students for key training, to meet the requirement of industry and enterprise on elite talents.

\section{Conduct simulation training}

Simulation training is the preparation to train students' practice hands-on skills. At present, innovation and entrepreneurship education simulation training in higher vocational colleges generally uses the sand table, such as physical sand table. In recent years, with the progress of electronic technology, the electronic sand table is adopted. Since the introduction into our country, the role of sand table simulation training in innovation and entrepreneurship teaching cannot be ignored. Students can use the sand table form to simulate corporate financial management, corporate site selection, procurement affaires, registration, capital operation, research and development and other aspects of production. Through the simulation of innovation and entrepreneurship related processes, in the actual innovation and entrepreneurship activities students can be familiar with business process, analyze market development status, and forecast market trends. Sand table simulation enables students close to the enterprise combat in the learning process, find problems in the simulation, and find a solution on their own, so as to effectively enhance their interest in learning and stimulate their learning potential. The simulation training can also help students adjust their mental attitude in advance, and have the psychological preparation for practical activities.

\section{Practical activities}

Practical activities are the key link in the process of innovation and entrepreneurship teaching, and play an important role in creating the innovation and entrepreneurship atmosphere and shaping the brand culture. There are a variety of forms of practical activities, including the following aspects. First, scientific and technological innovation and practical activities. Through scientific and technological innovation and practical activities, students can stimulate their enthusiasm and initiative of innovation and entrepreneurship, and better play their advantages, expertise and hobbies, as well as achieve personal individualized development, and improve their comprehensive ability and quality; second, social practice activities. Encouraging students to participate in a variety of social activities, and participate in social services and market research, to make them personally invested in the community and enterprises, more comprehensively understand the society and the status of market development, grasp the market trends, and strengthen the understanding of the industry. This will help students deepen their knowledge structure, improve their vocational skills and meet social needs; finally, community activities. Higher vocational colleges can encourage and support students to form innovation and entrepreneurship club or group, and conduct innovation and entrepreneurship activities in the form of associations, clubs and others. In addition, organize innovation and entrepreneurship seminars, set up communication platform, and regularly carry out innovation and entrepreneurship skills contest, to enable students to improve innovation and entrepreneurship ability in the exchange and competition. 


\section{Transformation of science and technology}

Scientific and technological achievements are the key to test the effectiveness of innovation and entrepreneurship education in higher vocational colleges. Therefore, higher vocational colleges should strengthen relationship with enterprises, scientific research institutions and governments so as to enhance the promotion and transformation of scientific and technological achievements. Scientific research institutions can provide technical support, management services, legal advisers and other services for students' innovation and entrepreneurship work, to ensure the smooth development of the research and development; enterprises are the main position in the application of scientific and technological achievements of higher vocational colleges. Effective transformation of scientific and technological achievements is conducive to the realization of our economy institutional reform, and industrial restructuring. The government indicates the development direction for the transformation of scientific and technological achievements, and also provides policy support for scientific research activities. As the intermediary, higher vocational colleges should all-round integrate enterprises, research institutions, government related resources to provide good service for the transformation of students' innovative scientific and technological achievements.

\section{Conclusions}

At present, there are still many shortcomings for the construction of innovation and entrepreneurship education ecosystem in higher vocational colleges in our country. How to speed up the construction of educational ecosystem has become the key of higher education reform. Through the integration of government, enterprise, higher vocational college and family, carry out theoretical education, training simulation, practical activities and science and technology transformation, improve students' ability of innovation and entrepreneurship, output high-quality talents to the industry and enterprises, and achieve the ultimate purpose of higher vocational colleges to serve the society.

\section{Acknowledgement}

Subject: Key research subject of college counselors in Jiangxi: Research on the Cooperative Development Mechanism of"Three Innovations" in Higher Vocational Colleges Based on Triple Helix Theory (15FYHZD12); Teaching reform research subject of Changzhou Institute of Engineering Technology: Research on Innovation and Entrepreneurship Education Curriculum System in Higher Vocational Colleges Based on Process Orientation (11430500216026).

\section{References}

[1] Wang Changheng. Research on the Construction of Innovation and Entrepreneurship Education Ecological Cultivation System in Colleges and Universities, Journal of Continuing Education, 2012 (02): 125-127.

[2] Tan Jianhua. Construction of Innovation and Entrepreneurship Education Ecosystem in Higher Vocational Colleges Based on Process Orientation, Education and Occupation, 2016 (23): 42-46.

[3] Lin Zuanhui. Characteristics and Construction of Innovation and Entrepreneurship Education Ecosystem of College Students, Educational Research, 2014 (09): 67-69.

[4] Zheng Lingtong. Study on Construction of Innovation and Entrepreneurship Education Ecosystem of College Students, Knowledge Economy, 2014 (09): 55-56. 